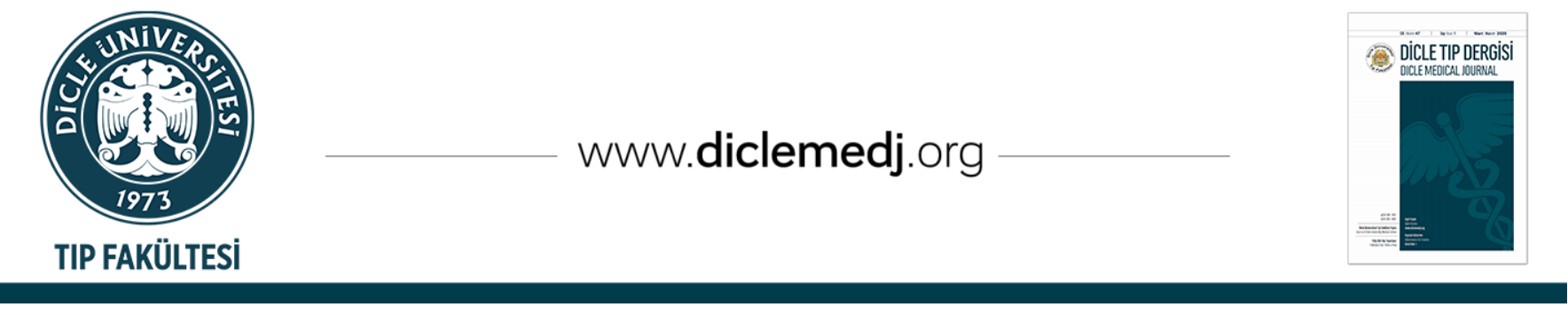

Özgün Araștırma / Original Article

\title{
Opere Kalça Kırığı Olgularında D Vitamini ve Biokimyasal Parametrelerin Değerlendirilmesi
}

\author{
Murat Mert ${ }^{\text {iD } 1}$, Cenk Ermutlu ${ }^{\text {iD } 2}$ \\ 1 Yeniyüzyıl Üniversitesi Tıp Fakültesi, Ortopedi ve Travmatoloji ABD. İstanbul, Türkiye \\ 2 Uludağ Üniversitesi Tıp Fakültesi Ortopedi ve Travmatoloji ABD. Bursa, Türkiye
}

Geliș: 23.04.2020; Revizyon: 29.05.2020; Kabul Tarihi: 30.05.2020

Öz

Giriş: Osteoporoz, yaşa bağlı olarak ortaya çıkan multifaktöryel bir durumdur ve artmış kalça kırığı insidansı ile ilişkilidir. Kemik döngüsü belirteçleri, osteoporoz varlığında yüksek oranda etkilenir. Bu çalışmamızda, kalça kırığı nedeniyle opere edilen yaşlı bireylerde D vitamini ve Parathormon (PTH) düzeylerini ve bu metabolitlerin serum fosfor (P) ve kalsiyum (Ca) metabolizması ile iliş̧isinin değerlendirilmesi amaçlanmıştır.

Yöntemler: İkinci basamak bir hastaneye kalça kırı̆̆ı nedeniyle başvuran ve replasman cerrahisi yapılan 43 hastanın serum 250HD3, PTH, Ca ve P düzeyleri retrospektif olarak incelendi. Hastalar, D vitamini düzeylerine göre gruplara ayrıldı. Yaş ve analiz edilen parametreler arasındaki korelasyon incelendi.

Bulgular: Çalışma kapsamında değerlendirilen hastalardaki D vitamini eksikliği insidansı \%74.4 iken, \%20.9 hastada D vitamini düzeylerinde yetersizlik söz konusu idi. Hasta grubunun \%4.7'sinde ise D vitamin seviyeleri normal düzeylerde saptandı $(\mathrm{p}<0.05)$. Yaş ve Serum 250HD3; Serum 250HD3 ve PTH seviyeleri arasında negatif, yaş ve PTH seviyeleri arasında ise pozitif korelasyon saptand $(\mathrm{p}<0.05 ; \mathrm{p}<0.01)$. Serum 250HD3 ve Ca, P düzeyleri arasında pozitif korelasyon $(\mathrm{p}<0.05 ; \mathrm{p}<0.05)$, serum PTH ve Ca, $\mathrm{P}$ arasında pozitif korelasyon $(\mathrm{p}<0.05 ; \mathrm{p}<0.05)$ saptandı.

Sonuç: Kalça kırı̆̆ı ile başvuran yaşlı hastalarda D vitamini hipovitaminozu insidansı \%95.5 olarak saptanmıştır. Düşük serum 250HD3 düzeylerinin artmış PTH düzeyleri ile ilişkili olduğunu doğrulamaktadır. Cerrahi sonrasında ve geriatrik yaş grubunda kalça kırığı riskinin önlenmesinde D vitamini ve Ca suplementasyonu ve serum 250HD3 ve Ca seviyelerinin düzenli aralıklarla kontrolü, koruyucu bir rol oynayacaktır.

Anahtar kelimeler: D vitamini, parathormon, kalça kırı̆̆ı̆. Kalsiyum, fosfor

DOI: 10.5798/dicletip.755774

Correspondence / Yazıșma Adresi: Murat Mert, Yeniyüzyıl Üniversitesi Tıp Fakültesi, Ortopedi ve Travmatoloji ABD. İstanbul, Türkiye e-mail: muratmertdr@gmail.com 


\title{
Evaluation of Vitamin D and Biochemical Parameters in Patients Operated For Hip Fracture
}

\begin{abstract}
Objective: Osteoporosis is a multifactorial condition that occurs with age and is associated with an increased incidence of hip fractures. Bone cycle markers are highly affected in the presence of osteoporosis. In this study, we aimed to evaluate vitamin D (250HD3), Parathormone (PTH) Calcium (Ca) and Phospor (P) levels in elderly individuals who were operated for hip fracture.

Methods: Serum 250HD3, PTH, Ca and P levels of 43 patients who applied to our hospital for hip fracture and who underwent replacement surgery were analyzed retrospectively. The patients were divided into groups according to their levels of Vitamin D. The correlation between age and analyzed parameters was studied.

Results: While the incidence of vitamin D deficiency was $74.4 \%$ in patients evaluated within the scope of the study, $20.9 \%$ of patients had insufficient vitamin D levels. In $4.7 \%$ of the patient group, vitamin D levels were found at normal levels ( $\mathrm{p}<0.05)$. There was a negative correlation between age and Serum 250HD3 levels, serum 250HD3 and PTH levels, and a positive correlation between age and PTH levels ( $p<0.05$; $p<0.01$ ). Correlation between serum 250HD3 and Ca, P levels was positive ( $<<0.05$; $p<0.05$ ).It was also positive between serum PTH and Ca, P $(\mathrm{p}<0.05 ; \mathrm{p}<0.05)$.

Conclusions: The incidence of vitamin D hypovitaminosis was found to be $95.5 \%$ in elderly patients presenting with hip fracture. It confirms that low serum 250HD3 levels are associated with increased PTH levels. Vitamin D and Ca supplementation and regular control of serum 250HD3 and Ca levels will play a protective role in preventing the risk of hip fracture after surgery and in the geriatric age group.
\end{abstract}

Keywords: Vitamin D, Parathormone, hip fracture, Calcium, Phospor.

\section{GİRIŞ}

Osteoporoz, dünya üzerinde çok sayıda erişkini etkileyen ve kalça kırı̆̆ı (KK) riskini artıran bir hastalıktır. Osteoporoz ileri yaş dönemde ortaya çıkardığı direkt ve dolaylı komplikasyonlar ile ileri yaş grubunda artmış mortalite ve morbidite ve düşük yaşam kalitesi ile ilişskilidir ${ }^{1}$.

KK riskinin ana belirleyicilerinden birisi kemiğin kuvveti ve kemiği meydana getiren elementlerin durumudur. Azalmış ve dengesiz bir dağılım gösteren kemik mineral yoğunluğu hem kadın hem erkek cinsiyetteki yaşlılarda düşme eğiliminde ve KK insidansındaki artış ile doğru orantılıdır. Eşlik eden kronik hastalıklar, menopoz, osteoblast aktivitesindeki azalma, bazı ilaçlar ve sporadik faktörler, kemik yoğunluğundaki azalmanın ana nedenlerindendir ${ }^{2}$.

PTH, 84 adet aminoasit içeren ve paratiroid bezi tarafindan salgılanan tek zincirli, polipeptit yapıda bir hormondur ve kalsiyum ve fosfor dengesinin ve kemik döngüsünün düzenlenmesinde önemli bir rol oynar³.
250HD3, D vitaminin dolaşımdaki ana metabolitidir ve insan ve memeli metabolizmasındaki ana rolü, iskelet mineralizasyonunu sağlamak amaciyla kalsiyum ve fosfor absorbsiyonunun gerçekleştirilmesidir ${ }^{3}$. Doğal D vitaminin kaynaklarının da sınırlı olması nedeniyle, ultraviyole işınlar aktif D vitamini sentezinin en önemli belirleyicilerindendir. Yaşla birlikte güneș ışı̆̆ına maruziyetin azalması, cilt ile ilişkili faktörler gibi nedenlerle D vitamini sentezi dramatik bir biçimde azalır ${ }^{4}$. Bununla birlikte, yaşla birlikte böbrek ve bağırsak fonksiyonlarındaki değişimlerin de Parathormon (PTH) ve 25-OH Vitamin D D3 (250HD3) emilimi ve kullanımında bozulmalara sebep olması beklenmektedir. Özellikle renal hastalıklarda gözlenen artmış serum fosfor düzeyi, PTH sekresyonunu artırarak, 250HD3'ün 1, 250HD3'e hikroksilasyonunu azaltır. Azalmış aktif D vitamini düzeyleri, bozulmuş kalsiyum absorbsiyonu ve hipokalsemi ile sonuçlanır. Düşük düzeyde seyir gösteren D vitamini seviyeleri, PTH seviyesinin artışına neden olur ve bunun sonucunda, kemiğin yapısal elemanlarının miktarında aşamalı bir düşüş ve 
kemik yapısında ilerleyici bir bozulma meydana gelir. Düşük D vitamini seviyelerinin azalmıș kas tonusu ve nöromüsküler kontrol, dolayısıyla da artmış düşme riski ile ilişkili olduğunu gösteren çalışmalar da bulunmaktadır ${ }^{5}$.

$\mathrm{Bu}$ çalışmada KK ile başvuran ve total kalça protezi ya da hemiartroplasti uygulanan yaşlı hastalarda D vitamini ve PTH seviyelerinin ve bu metabolitlerin düzeyinin serum fosfor (P) ve kalsiyum (Ca) metabolizması ile ilişkisinin değerlendirilmesi amaçlanmıştır.

\section{YÖNTEMLER}

$\mathrm{Bu}$ çalışma 2013 ve 2014 yılları arasında merkezimize başvuran KK hastalarının laboratuvar sonuçlarının retrospektif olarak değerlendirilmesi ile oluşturulmuştur. Ortopedi ve Travmatoloji servisine $\mathrm{KK}$ nedeniyle başvuran ve PTH, 250HD3, P, Ca analizi yapılmış olan 43 olgu (34 Kadın, 11 Erkek) çalışma kapsamında değerlendirilmiştir. Altmış beş yaş altındaki hastalar, yüksek enerjili travmaya bağlı kırıklar ve yakın tarihte D vitamini suplementasyonu alan hastalar, çalışma kapsamına alınmamıștır. Çalışma, lokal etik komite tarafından onaylanmış (2012/77) ve Helsinki Bildirgesi koşullarına uygun olarak yürütülmüștür.

Serum PTH, P ve Ca değerlerinin referans aralıkları, analiz kitini üretici firmanın belirttiği şekilde, sırasıyla $15-65 \mathrm{pg} / \mathrm{mL}, 2.5-4.5 \mathrm{mg} / \mathrm{dL}$ ve $8.8-10.2 \mathrm{mg} / \mathrm{dL}$ şeklindedir.

Normal 250HD3 seviyesi ise $\geq 30 \mathrm{ng} / \mathrm{mL}$ olarak kabul edilmiştir. $<20 \mathrm{ng} / \mathrm{mL}$ düzeyindeki 250HD3 seviyesi D vitamini eksikliği olarak kabul edilirken, 21-29 ng / $\mathrm{mL}$ D düzeyindeki 250HD3 seviyesi yetersizlik olarak değerlendirilmiştir6. Tüm laboratuvar analizleri aynı hastane laboratuvarında aynı metodlar kullanılarak gerçekleştirilmiştir.

\section{İstatistiksel Analiz}

Tüm veriler SPSS sürüm 14.0 (SPSS Inc., Şikago, IL, ABD) bilgisayar yazılımı kullanılarak yapıldı. Korelasyon çalışmaları için Pearson'ın korelasyon testi kullanıldı. Gruplar arası karşılaştırmalarda Ki-kare testi kullanıldı. Tüm veriler \%95 güven aralığında kabul edildi ve istatistiksel anlamlılık düzeyi $\mathrm{p}<0.05$ olarak belirlendi.

\section{SONUÇLAR}

Çalışma kapsamında değerlendirilen parametrelerin ortalama değerlendirmesi ve demografik veriler Tablo I'de gösterilmektedir. Hastaların ortalama yaşı $71 \pm 7 \quad(62-83)$ yıl olarak saptanmıştır. Dokuz (\%21) hastaya total kalça protezi, 34 (\%79) hastaya ise hemiartroplasti uygulanmıştır. Ortalama 250HD3 düzeyi $15.2 \pm 9.11 \mathrm{ng} / \mathrm{mL}, \quad$ PTH $107.6 \pm 51.4 \mathrm{pg} / \mathrm{mL}, \mathrm{P} 4.2 \pm 0.7 \mathrm{mg} / \mathrm{dL}$, Ca $9.2 \pm 1.8$ $\mathrm{mg} / \mathrm{dL}$ şeklindedir. Hastaların tamamında serum PTH düzeyleri referans aralığın üzerindedir.

Tablo I: Verilerin çalışma grubundaki dağılımı

\begin{tabular}{|l|c|c|c|c|}
\hline Parametreler & $\begin{array}{c}\text { Ortalama } \\
\mathbf{\pm S S}\end{array}$ & $\begin{array}{c}\text { En } \\
\text { Düşük }\end{array}$ & En Yüksek & Median \\
\hline Yaş (yıl) & $71 \pm 7$ & 62 & 83 & 66 \\
\hline $\begin{array}{l}\text { 25OHD3 } \\
\text { (ng/mL) }\end{array}$ & $15.2 \pm 9.11$ & 6,2 & 31,6 & 17,4 \\
\hline PTH (pg/mL) & $107.6 \pm 51.4$ & 67 & 188 & 121 \\
\hline $\begin{array}{l}\text { Inorganik Fosfor } \\
\text { (mg/dL) }\end{array}$ & $4.2 \pm 0.7$ & 3,2 & 4,8 & 4,0 \\
\hline $\begin{array}{l}\text { Kalsiyum } \\
\text { (mg/dL) }\end{array}$ & $9.2 \pm 1.8$ & 8,3 & 11,2 & 9,5 \\
\hline
\end{tabular}

Çalışma kapsamında değerlendirilen hastalardaki D vitamini eksikliği insidansı $\% 74,4$ iken, \%20,9 hastada 250HD3 düzeylerinde yetersizlik söz konusu idi. Hasta grubunun \%4,7'sinde ise 250HD3 seviyeleri normal düzeylerde saptandı (Tablo II). Serum 250HD3 düzeyi yetersiz olarak saptanan hastalar ile 250HD3 eksikliği bulunan ve 
normal düzeylerde 250HD3'e sahip hastaların oranında anlamlı derecede farklılık saptandı.

Tablo II: Hasta grubunun D vitaminin durumlarına göre dağılımı

\begin{tabular}{|l|c|c|c|}
\hline \multicolumn{1}{|c|}{ D vitamini Durumu } & Sayı & Yüzde & p değeri \\
\hline D vitamini eksikliği & 32 & 74,4 & $<\mathbf{0 . 0 1}$ \\
\hline D vitamini yetersizliği & 9 & 20,9 & $\mathbf{0 . 0 1}$ \\
\hline Normal D vitamini düzeyi & 2 & 4,7 & $<\mathbf{0 . 0 0 0 1}$ \\
\hline
\end{tabular}

Parametreler arasındaki korelasyon verileri incelendiğinde, yaş ve Serum 250HD3 ( $\mathrm{r}=$ $\left.0.47^{*}, \mathrm{p}<0.05\right)$; Serum 250HD3 ve PTH seviyeleri arasında negatif $\left(\mathrm{r}=-0.86^{* *}, \mathrm{p}<0.01\right)$, yaş ve PTH seviyeleri arasında ise pozitif korelasyon $\left(r=0.64^{*}, \mathrm{p}<0.05\right)$ saptand. Serum $250 H D 3$ ve $\mathrm{Ca}\left(\mathrm{r}=0.58^{*}, \mathrm{p}<0.05\right)$ ve $\mathrm{P}\left(\mathrm{r}=0.52^{*}\right.$, $\mathrm{p}<0.05)$ arasinda pozitif korelasyon saptand. Serum PTH ve Ca $(r=0.61 *, p<0.05)$ ve $P(r=$ $0.48^{*}, \mathrm{p}<0.05$ ) arasinda pozitif korelasyon saptandı. Tüm korelasyonların istatistiksel olarak anlamlı düzeyde olduğu gözlendi (Tablo III).

Tablo III: Parametreler arasındaki korelasyon matriksi.

\begin{tabular}{|c|c|c|c|c|c|}
\hline Parametreler & Yaş & 250HD3 & PTH & P & Ca \\
\hline 250HD3 & $\mathbf{- 0 . 4 7 *}^{*}$ & & & & \\
\hline PTH & $\mathbf{0 . 6 4}^{*}$ & $\mathbf{- 0 . 8 6}^{* *}$ & & & \\
\hline P & 0.20 & $\mathbf{0 . 5 2}^{*}$ & $\mathbf{0 . 4 8}^{*}$ & & \\
\hline Ca & 0.36 & $\mathbf{0 . 5 8}^{*}$ & $\mathbf{0 . 6 1}^{*}$ & $\mathbf{0 . 8 9 *}$ & \\
\hline${ }^{*}<<0.05^{* *} p<0.01$
\end{tabular}

\section{TARTIŞMA}

Vitamin D ve metabolitleri, $\mathrm{PTH}, \mathrm{P}$ ve $\mathrm{Ca}$ metabolizması ve kemik döngüsü arasındaki karmaşık ve detaylı ilişki, özellikle ileri yaştaki hastalardaki artmış düşme ve KK başta olmak üzere fraktür risklerinin değerlendirilmesinde oldukça önemlidir. Son yıllarda vitamin D durumunun değerlendirilmesi amacıyla serumda 250HD3 düzeyinin ölçümü yaygınlık kazanmıștır7.

Çalışmamız KK nedeniyle kalça protez cerrahisi yapılan 65 yaş üzeri olgularda kemik homeostaz parametrelerinin değerlendirilmesini amaçlamaktadır. Sonuçlarımıza göre, değerlendirilen grupta $D$ vitamini yetersizliği ve eksikliği oranlarının anlamlı derecede yüksek olduğu, ve düşük serum 250HD3 düzeylerinin yaş ile ve PTH düzeyleri ile negatif korelasyon gösterdiği saptanmıştır. $\mathrm{Bu}$ veriler, global düzeyde yapılan diğer çalışmaların bulguları ile de uyumludur? .

Düşük serum 250HD3 düzeylerinin ve buna bağlı olarak artmış PTH düzeyine bağlı kemik yıkımının yaşlılarda artmış düşme ve $\mathrm{KK}$ insidansı ile lişkili olduğunu belirten çalışmalar mevcuttur ${ }^{8,9}$. Çalışmalar KK ile başvuran geriatrik kadın popülasyondaki D vitamini eksikliği insidansının \%21,6-67 oranında değiştiğini göstermektedir ${ }^{10}$. KK ile başvuran 335 postmenapozal kadın hasta ile yapılan bir çalışmada, düşük 25(OH)D3 düzeyleri ve sekonder hiperparatiroidizmin KK'a eşlik eden üst ekstremite fraktürleri ile de yakın ilişkide olduğu gösterilmiștir ${ }^{11}$. Bulgaristan'da kış döneminde bakım evinde yaşayan bireyler üzerinde yapılan güncel bir çalışmada, her dört kişiden üçünde vitamin D eksikliği saptanmış ve bu hastaların \%8'inde KK gerçekleșmiştir ${ }^{12}$. Sakuma ve ark. tarafindan yürütülen bir çalışmada, KK hastalarının \%62'sinde 250HD3 düzeylerinin düşük olduğu ve PTH seviyelerinin de bu durumun bir sonucu olarak \% 19,4 oranında hastada $65 \mathrm{pg} / \mathrm{ml}$ 'nin üzerinde saptandığı belirtilmiştir9. Diğer bir çalışmada ise, sekonder hiperparatiroidizm belirteci olarak artmış PTH konsantrasyonu, 250HD3 eksikliği olan hastaların \%45,7'inde gözlenmiștir ${ }^{13}$. Bu çalışmada, 250HD3 düzeyine bağlı olmaksızın, hasta grubunun tamamında artmış PTH düzeyi gözlenmiştir. Bu durumun, hastaların ortalama serum kreatinin düzeyi ile ilişkili olarak, yaş ile birlikte bozulan renal fonksiyona bağlı olarak ortaya çıkmış olabileceği kanaatindeyiz. Karaciğerde depolanan 25(OH)D3'ün 1. karbon atomuna hidroksil grubu eklenmesiyle oluşan ve D vitamininin aktif formu olan 1,25(OH)D3 
sentezi böbrekte gerçekleşmektedir. $\mathrm{Bu}$ nedenle, renal işlevlerdeki yaşa ve diğer nedenlere bağlı gerilemenin geriatrik popülasyonda vitamin D eksikliği ve yetersizliği nedenlerinden biri olduğu bilinmektedir. Madsen ve ark., KK hastalarında sekonder hiperparatiroidizm ve 1 ylllk mortalite arasında anlamlı bir ilişki bulunduğunu belirtmiştir. Ek olarak sekonder hiperparatiroidizm varlığında prognozun D vitamini düzeylerinden bağımsız olarak daha kötü seyrettiğini de vurgulamışlardır ${ }^{14}$.

Kemik, yaşam süresi boyunca sürekli olarak yeniden modellenen dinamik bir dokudur, ve osteoblast ve osteklastların dengeli ve bileşik aktiviteleri ile sağlamlığını ve dayanıklılığını muhafaza etmektedir. Kemik modellenmesinin karmaşık süreci, bir dizi karmaşık endojen ve eksojen faktörler tarafından düzenlenir. Organizmada bulunan Ca'un \%99'u kemik yapısinda hidroksiapatit kristallerinin yapısında bulunur. Kemik, aynı zamanda dolaşımdaki Ca düzeyinin sabit tutulabilmesi için bir rezervuar işlevi de göstermektedir ${ }^{15}$.

Kemik kırıklarının iyileşmesi ise, birçok hücre tipi ve büyüme faktörleri ve sitokinler gibi mediatörlerin ilişkisini içeren üç aşamalı (inflamasyon, tamir, yeniden şekillenme) bir süreçtir. İnflamasyon fazı doku ve hücre hasarı ile karakterize, kırık alanında oluşan hematoma immün sistem hücrelerinin reaksiyonu şeklinde ortaya çıkar. Tamir aşamasında intramembranöz ve endokondral kemikleşme kallus oluşumunu sağlar. Yeniden şekillendirmede ise, yeni oluşan kemik dokusu lamellar kemik dokusuna dönüşerek kemiğin şeklinin ve stabilitesinin devamının sağlanmasını amaçlar. Osteoporoz süresince oluşan tüm yapısal ve sistemik değişiklikler, bu sıkı denetlenen sürecin unsurlarının işlevlerinde aksaklıklara ve bozulmalara neden olmaktadır ${ }^{16}$.

Vitamin D reseptörü, DNA üzerindeki vitamin D yanıt elemanlarına bağlanarak hedef genlerin aktiflenmesini sağlar. $\mathrm{Bu}$ hedef genlerin en önemlileri ise, kemik ile ilişkili osteokalsin, osteopontin (SPP1) ve tumour necrosis factor superfamily member 11 (TNFSF11)'dir ${ }^{17}$.

Vitamin D ve türevlerinin sağlıklı bir kemik yapısı üzerindeki bilinen etkisi, ve yaşla birlikte artmış vitamin $\mathrm{D}$ eksikliği ve yetersizliği prevalansı nedeniyle, vitamin düzeylerini optimum seviyede tutabilmek amacıyla ek tedaviler ve suplementer içeriklerin risk grubundaki bireyler tarafindan kullanılması önerilmektedir. Ulusal Osteoporoz Kurumu'nun rehberleri, 50 yaşın üzerindeki kadınlar gibi özellikle yüksek risk grubundaki bireyler için diet ile vitamin D ve Ca alımının yeterli olmadığ durumlarda bisfosfonatlar ve diğer tedavilerin yanı sira vitamin destek tedavi verilmesini de önermektedir ${ }^{18}$. Çalışmamız kapsamında saptanmış düşük 250HD3 düzeylerinin multifaktöryel olabileceğinden hastaların geniş kapsamlı değerlendirilmesi ve tekrarlayan kırıkların ve diğer morbiditelerin önlenebilmesi amaciyla rutin olarak D vitamin suplementasyonunun takibi gerekmektedir. Kırık iyileşmesinin erken dönemlerinde düşük dozda verilen rekombinant insan PTH bileşiklerinin osteogenez indükleyici gen olan Runx2'nin gen ve protein seviyesinde ekspresyonunu artırarak kemik iyileşmesini hızlandırdığı, kırık bölgesindeki mineral tuz konsantrasyonunu ve epifizyal hacmi artırdığı ve gerilme direncini yükselttiği belirtilmektedir. PTH içeren preparatlar, osteoporoz tedavisinde de yaygin olarak kullanılmaktadır ${ }^{19}$.

Fizyolojik koşullarda, besin ile alınan Ca'un yaklaşık \% 30-40'ı barsaklar tarafından absorbe edilir. Total serum Ca düzeyi, mide asiditesi, yaş ve Vitamin D düzeyi gibi koşullar, Ca emilim oranı ve hızı üzerinde etki gösterir. Ca seviyesi azaldığında, paratiroid bezler üzerinde bulunan Ca-ilişkili reseptörler, PTH salınımını uyarırlar. Dolaşıma verilen PTH, böbrek üzerinde bulunan reseptörüne bağlanarak Ca geri emilimini, fosfat 
atılımını ve 1,25-VitD3 üretimini artırıcı yönde etki gösterir. Dolaşımda bulunan PTH and 1,25VitD3 osteoblastlar üzerinde bulunan kendi reseptörlerine bağlanarak receptor activator of $\mathrm{NF}-\kappa \mathrm{B}$ ligand (RANKL) ekspresyonunu, dolayısıyla osteoklastik kemik rezorpsiyonun ve dolaşıma Ca ve P salınımını sağlar ${ }^{20}$.

Diyetle yetersiz miktarda kalsiyum ve D vitamini alımı, güneş altında ve açık havada geçirilen zamanın azlığı yetersiz beslenme, yaşa bağlı olarak renal ve hepatik sistemlerdeki değișimler D vitamini hipovitaminozunun en önemli nedenleri arasında bulunmaktadır. Çalışmamı kapsamında değerlendirilen hastaların tamamı yaşamını metropol koşullarında sürdürmektedir. $\mathrm{Bu}$ durum da çevre kirliliği ve kısıtlı güneş ışığı gibi faktörleri beraberinde getirmektedir. Ek olarak çalışmamız kapsamında KK ile ile başvuran kadın hastaların oranındaki yükseklik dikkate alınması gereken faktörlerden biridir. Menopoz sonrasında değişen hormon dengesine bağlı olarak azalan kemik yoğunluğunun yanı sıra, açık havada geçirilen sürenin kadın bireylerde erkek bireylere oranla düşük olması da D vitamini hipovitaminozunun nedenleri arasında incelenebilir ${ }^{21}$.

Bağırsaklardan kalsiyum emiliminin ana fizyolojik düzenleyicisi aktif D vitamini formu olan, 1,25 dihidroksivitamin D3 (1,25 (OH)D3)'tür. Yaşa bağlı olarak bu hormonun sentezinde veya bağırsakların hormona yanıtında meydana gelen değişiklikler de yaş ile birlikte ortaya çıkan azalmış kalsiyum emiliminden sorumludur. Böbrek 250HD31alfa-hidroksilaz aktivitesinde azalma, böbrek fonksiyon bozukluğuna sekonder azalan enzimatik aktivite ve $250 \mathrm{H}$ 3'ün biyoyararlanımının yaşa bağlı azalması da D vitamini hipovitaminozunun nedenleri arasındadır 22 .

Düşük 250H D3 seviyeleri 1,25 (OH)D2 ve kalsiyum emiliminde bozulmaya yol açar ve bu da kalsiyum homeostazını düzenleyebilmek amacıyla artmış PTH sentezi ile sonuçlanır. Bu ikincil hiperparatiroidizm, kemik döngüsünün artışı, kemik kaybı ve buna bağlı olarak artmış KK riski ile orantılıdır. Güncel bir geniş katılımlı çalışmada KK ameliyatından sonraki 7 gün içinde 250.000 IU kolekalsiferol ile tedavinin ve ardından düzenli $\mathrm{D}$ vitamini kullanımının düşme oranını azaltabileceğini gösteren bulgular elde edilmiştir ${ }^{23}$.

250HD3 düzeyinin normal seviyelerde seyrettiği bireylerde KK insidansının oldukça düşük olduğu gösterilmiştir. 615 postmenopozal kadın üzerinde yapılan bir araştırmada, normal 250HD3 düzeyine sahip olanlarda KK oranı \%3,7 olarak saptanmıştır ${ }^{24}$. Normal D vitamini düzeyine sahip ve ileri derecede düşük serum 250HD3 düzeylerine kıyasla daha yüksek düzeyde $\mathrm{D}$ vitamini seviyesine sahip bireylerin D vitamini hipovitaminozlu bireylere klyasla KK operasyonu sonrasinda daha erken mobilize olduğu ve fizik tedaviden daha yüksek oranda fayda gördüğ̈ saptanmıştır.

Öte yandan, 25(OH)D ve diğer vitamin eksikliklerinin nedeni olabilecek nedenlerin ortadan kaldırılması, geriatrik hastalarda hem düşmeye bağlı, hem de spontan kırıkların oranındaki azalmanın yanı sıra, artmış mobilite ve yaşam kalitesi ile ilişkilidir. Kalça kırığı cerrahisi uygulanan kardiyavasküler riskli hastalar (FOCUS) kohortundan kesitsel bir analizi içeren güncel bir çalışmada, 25(OH)D düzeyi <12 ng / $\mathrm{mL}$ olan hastalarla karşılaştırıldığında, 25(OH)D konsantrasyonu daha yüksek olanlarda kalça kırığı ameliyatını takip eden 30. günde ambulasyon ve hareketlilik oranlarında anlamlı bir farklılık saptanmıştır ${ }^{25}$. Ancak, D vitamini eksikliği ya da yetersizliğinin yürüme ve dengedeki beceri ile ilişkisi tam olarak açıklanamamaktadır. D vitamini eksikliğinde bozulmuş kemik trabeküler yapısının kemikte dengesiz yapılanmaya neden olarak, iskelet dengesi ve aksiyal simetride olumsuz rol oynadığını 
düşünmekteyiz. Ek olarak, geriatrik hastalarda yalnızca vitamin eksiklikleri değil, uygun ölçekler ve biyokimyasal belirteçler kullanılarak genel beslenme yeterliliği ve olası malnütrisyon koşullarının da değerlendirilmesi gerekmektedir. Özellikle demans varlığında bozulmuş nütrisyonel durum ve dehidratasyon önemli bir mortalite nedeni olduğundan, bu grup hastalar yakından takip edilmelidir.

Çalışmamız kapsamında değerlendirilen hastaların verileri, mevsimsel bazda incelenmemektedir. D vitamini hipovitaminozu insidansının kış ve ilkbahar aylarında daha fazla olduğu bilinmektedir. 0 nedenle, mevsimlere göre ayrılan hasta gruplarında farklı D vitamini düzeylerinin saptanabilmesi olasılı̆̆ bulunmaktadır. Diğer taraftan, PTH düzeylerinin ve vitamin $\mathrm{D}$ metabolizmasının böbrek fonksiyonları ile yakın ilişkide olduğu bilindiğinden, hasta grubumuzda renal fonksiyon değerlendirmesi yapılmamıştır. Dolayisiyla, hasta grubumuzun kemik metabolizması parametreleri üzerinde böbrek fonksiyonlarının etkisi ile ilgili bir çıkarım yapılamamaktadır.

Sonuç olarak, bu çalışmamız D vitamini eksikliğinin KK hastalarında yüksek düzeyde yaygın olduğunu ve düşük serum 250HD3 düzeylerinin artmış PTH düzeyleri ile ilişkili olduğunu doğrulamaktadır. Bununla birlikte, hastaların günlük işlevlerini, yiyecek ve giyim alışkanlıklarını, bilişsel düzeylerini ve eşlik eden komorbiditelerini de kapsam içerisinde değerlendirecek daha geniş düzeyli çalışmalara ihtiyaç duyulmaktadır. Ek olarak, serum osteokalsin, kemik spesifik alkalen fosfataz, idrar deoksipiridinolin ve N-terminal çaprazbağlı Tip 1 kollajen telopeptid (NTx) düzeyi ölçümü gibi kemik rezorpsiyonunun değerlendirmesinde kullanılabilecek özgül ve duyarlı belirteçleri içeren çalışmalar da osteoporoz ve kırık tedavisinde yeni seçeneklerin belirlenebilmesi amacıyla öncü nitelikte olacaktır.
Etik Kurul Kararı: Çalışma, lokal etik komite tarafından onaylanmış (2012/77) ve Helsinki Bildirgesi koşullarına uygun olarak yürütülmüștür.

Çıkar Çatışması Beyanı: Yazarlar çıkar çatışması olmadığını bildirmişlerdir.

Finansal Destek: Bu çalışma her hangi bir fon tarafından desteklenmemiştir.

Declaration of Conflicting Interests: The authors declare that they have no conflict of interest.

Financial Disclosure: No financial support was received.

\section{KAYNAKLAR}

1. Pinar G, Pinar T, Dogan N, et al. Osteoporosis risk factors in the women over 45-years old. Dicle Med J. 2008; 36: 258-66.

2. Türkyılmaz AK, Kurt EE, Devrimsel G. The effect of serum vitamin $D$ level and bone mineral density on balance and the risk of falling in postmenopausal women. Dicle Med J. 2013; 40: 391-5.

3. Iolascon G, Di Pietro G, Gimigliano F. Vitamin D supplementation in fractured patient: how, when and why. Clin Cases Miner Bone Metab. 2009; 6: 120-4.

4. Ramason R, Selvaganapathi N, Ismail NH, Wong WC, Rajamoney GN, Chong MS. Prevalence of vitamin d deficiency in patients with hip fracture seen in an orthogeriatric service in sunny singapore. Geriatr Orthop Surg Rehabil. 2014; 5: 82-6.

5. Mesa Ramos M. Vitamin D and fragility fractures. Rev Osteoporos Metab Miner. 2017; 9 Supplement: 40-4.

6. Holick MF, Binkley NC, Bischoff-Ferrari HA, et al. Evaluation, treatment, and prevention of vitamin D deficiency: an Endocrine Society clinical practice guideline. J Clin Endocrinol Metab. 2011; 96: 1911-30. 
7. Sahota O, Mundey MK, San P, et al. The relationship between vitamin $\mathrm{D}$ and parathyroid hormone: calcium homeostasis, bone turnover, and bone mineral density in postmenopausal women with established osteoporosis. Bone. 2004; 35: 312-9.

8. Dhanwal DK, Sahoo S, Gautam VK, Saha R. Hip fracture patients in India have vitamin D deficiency and secondary hyperparathyroidism. Osteoporos Int. 2013; 24: 553-7.

9. Sakuma M, Endo N, Oinuma T, et al. Vitamin D and intact PTH status in patients with hip fracture. Osteoporos Int. 2006; 17: 1608-14.

10. Drampalos E, Oikonomidis L, Oakley J, Michos I, Chronopoulos E. Vitamin D status and bone turnover marker levels in Greek women with fragility hip fracture. International Journal of Orthopaedics Sciences. 2017; 1: 564-7.

11. Lv JT, Zhang YY, Tian SQ, Sun K. Serum of 25Hydroxyvitamin D and Intact Parathyroid Hormone Levels in Postmenopausal Women with Hip and Upper Limb Fractures. J Am Geriatr Soc. 2016; 64: 1068-72.

12. Shinkov A, Borissova AM, Dakovska L, et al. Differences in the prevalence of vitamin D deficiency and hip fractures in nursing home residents and independently living elderly. Arch Endocrinol Metab. 2016; 60: 217-22.

13. Fisher AA, Davis MW. Calcium-PTH-vitamin $\mathrm{D}$ axis in older patients with hip fracture. Osteoporos Int. 2007; 18: 693-7.

14. Madsen CM, Jørgensen HL, Lind B, et al. Secondary hyperparathyroidism and mortality in hip fracture patients compared to a control group from general practice. Injury. 2012; 43: 1052-7.

15. Argyrou C, Karlafti E, LampropoulouAdamidou K, et al. Effect of calcium and vitamin D supplementation with and without collagen peptides on bone turnover in postmenopausal women with osteopenia. J Musculoskelet Neuronal Interact. 2020; 20: 12-17.
16. Claes L, Recknagel S, Ignatius A. Fracture healing under healthy and inflammatory conditions. Nat Rev Rheumatol. 2012; 8: 13343.

17. Christakos S, Dhawan P, Verstuyf A, Verlinden L, Carmeliet G. Vitamin D: Metabolism, Molecular Mechanism of Action, and Pleiotropic Effects. Physiol Rev. 2016; 96: 365-408.

18. Cosman F, de Beur SJ, LeBoff MS, et al. Clinician's Guide to Prevention and Treatment of Osteoporosis. Osteoporos Int. 2014; 25: 2359-81.

19. Tsuchie H, Miyakoshi N, Kasukawa Y, Aonuma $\mathrm{H}$, Shimada $\mathrm{Y}$. Intermittent administration of human parathyroid hormone before osteosynthesis stimulates cancellous bone union in ovariectomized rats. Tohoku J Exp Med. 2013; 229: 19-28.

20. Suda T, Takahashi N, Udagawa N, Jimi E, Gillespie MT, Martin TJ. Modulation of osteoclast differentiation and function by the new members of the tumor necrosis factor receptor and ligand families. Endocr Rev. 1999; 20: 345-57.

21. Atli T, Gullu S, Uysal AR, Erdogan G. The prevalence of Vitamin D deficiency and effects of ultraviolet light on Vitamin D levels in elderly Turkish population. Arch Gerontol Geriatr. 2005; 40: 53-60.

22. Lai JK, Lucas RM, Clements MS, Roddam AW, Banks E. Hip fracture risk in relation to vitamin D supplementation and serum 25hydroxyvitamin D levels: a systematic review and meta-analysis of randomised controlled trials and observational studies. BMC Public Health. 2010; 10: 331.

23. Mak J. Optimising Vitamin D Levels after Hip Fractures. In: Gowder S, ed. A Critical Evaluation of Vitamin D - Basic Overview. Rijeka: IntechOpen; 2017. 
24. von Mühlen DG, Greendale GA, Garland CF, 25. Hao L, Carson JL, Schlussel Y, Noveck H, Wan L, Barrett-Connor E. Vitamin D, Shapses SA. Vitamin D deficiency is associated parathyroid hormone levels and bone mineral with reduced mobility after hip fracture density in community-dwelling older women: surgery: a prospective study [published online the Rancho Bernardo Study. Osteoporos Int. ahead of print, 2020 Feb 19]. Am J Clin Nutr. 2005; 16: 1721-6. 2020;nqaa029. doi:10.1093/ajcn/nqaa029 